\title{
Analysis of factors related to death of severe acute pancreatitis
}

\author{
Chen Ji-jun, Li Chao, Wang Yan-jun, Zhao Bing-gang, Han Qiang, Yin Wen ${ }^{*}$ \\ From 2012 PLA Emergency Medicine Annual Congress \\ Beijing, China. 9-12 November 2012
}

\section{Background}

Severe acute pancreatitis (SAP) is defined as pancreatitis in the context of acute organ dysfunction, the mortality rate of which is still high. The present study was undertaken to investigate the risk factors of the mortality of SAP.

\section{Methods}

Data of 312 patients of SAP admitted to our hospital from January 2010 to May 2012 were reviewed.All patients were divided into 2 groups, the death group and the survival group. The factors related to death of SAP were analyzed with Logistic regression analysis.

\section{Results}

Sixty-seven of 312 patients $(24.48 \%)$ died. There were significant differences between two groups in age, body mass index, length of stay hospital, APACHE II score, multiple organ dysfunction syndrome (MODS) and abdominal compartment syndrome, all $P<0.05$.

\section{Conclusions}

MODS, especially respiratory dysfunction and renal dysfunction, is the main factors relating to mortality of SAP, whereas ACS, Balthazar CT class, infection, and age may impact death. Therefore early management of acute pancreatitis should be focused on the prevention and management of respiratory dysfunction and renal dysfunction.

Published: 18 December 2012

* Correspondence: xjyyyw@@mmu.edu.cn

Department of Emergency Xijing Hospital, the Fourth Military Medical University, Changle Xilu Road No.127, Xi'an 710032, China
doi:10.1186/1471-227X-12-S1-A8

Cite this article as: Ji-jun et al:: Analysis of factors related to death of severe acute pancreatitis. BMC Emergency Medicine 2012 12(Suppl 1):A8.
Submit your next manuscript to BioMed Central and take full advantage of:

- Convenient online submission

- Thorough peer review

- No space constraints or color figure charges

- Immediate publication on acceptance

- Inclusion in PubMed, CAS, Scopus and Google Scholar

- Research which is freely available for redistribution
C Biomed Central
C Biomed Central

(C) $2012 \mathrm{Ji}$-jun et al; licensee BioMed Central Ltd. This is an Open Access article distributed under the terms of the Creative Commons Attribution License (http://creativecommons.org/licenses/by/2.0), which permits unrestricted use, distribution, and reproduction in any medium, provided the original work is properly cited. 